\title{
Pyruvate Formation and Sugar Metabolism in an Amino Acid-Producing Bacterium, Brevibacterium flavum
}

\author{
Michiko MORI and Isamu SHIIO \\ Central Research laboratories, Ajinomoto Co., Inc., \\ Kawasaki-ku, Kawasaki, Kanagawa 210, Japan
}

Received July 2, 1986

\begin{abstract}
A Brevibacterium flavum mutant lacking pyruvate kinase, No. 70, grew on glucose, fructose and sucrose as well as the original wild strain did, but was unable to grow on ribose or gluconate unless pyruvate was added. Mutants that required pyruvate for growth on ribose were derived directly from the wild strain. Many of them were completely or partially defective in pyruvate kinase activity. These pyruvate kinase mutants were also unable to grow on gluconate. A phosphoenolpyruvate (PEP) : sugar phosphotransferase system (PTS) was found in B. flavum, which catalyzed the formation of pyruvate and sugar phosphate from PEP and sugar. The system required $\mathrm{Mg}^{2+}$, acted on glucose, fructose, mannose, glucosamine and 2-deoxyglucose, and existed in the cells grown on any of the carbon sources tested. Cells grown on fructose, mannitol and sucrose, however, exhibited higher PTS activities on fructose than those grown on others. Glucose PTS activity was about 20fold stronger than that of glucokinase. Other sugar metabolic enzymes, inducible mannitol dehydrogenase, gluconokinase, ribokinase and maltase, as well as constitutive invertase were also detected. Oxaloacetate decarboxylase and malic enzyme, which also catalyzed the pyruvate formation, were found in B. flavum, but the latter activity was very low in cells grown on glucose. The levels of these enzymes in pyruvate kinase mutants unable to grow on ribose or gluconate derived from the wild strain were almost identical to those in the wild-type strain.
\end{abstract}

Since phosphoenolpyruvate (PEP) is a branch-point intermediate in the sugar metabolism for amino acid biosynthesis, studies on enzymes catalyzing PEP metabolism seem interesting, especially for an amino acidproducing bacterium, Brevibacterium flavum. Studies on PEP carboxylase ${ }^{1)}$ which catalyzes the formation of oxaloacetate, an intermediate in amino acid biosynthesis, and on pyruvate kinase $(\mathrm{PK})^{2)}$ which catalyzes the first step of degradation of PEP to $\mathrm{CO}_{2}$ were reported previously.

Pyruvate produced from PEP via the PK reaction is not only oxidized to yield $\mathrm{CO}_{2}$ but also used for the biosynthesis of various essential cell constituents. The growth on glucose of mutants lacking PK, however, was substantially identical to that of the wild-type strain, suggesting that enzymes other than PK might serve to form sufficient pyruvate for growth.

The present study revealed that the PEP : sugar phosphotransferase system (PTS) as well as PK significantly contribute to the pyruvate formation during growth on glucose, whereas only PK is responsible for the formation during growth on sugars which are not metabolized via the PTS reaction.

\section{MATERIALS AND METHODS}

Chemicals. PEP, ADP and ATP were purchased from Sigma Chemical Co., dithiothreitol from Calbiochem, and NAD, NADH and NADP from Boehringer Mannheim $\mathrm{GmbH}$. All the enzymes used for enzyme assays and for the metabolite determinations were obtained from the latter company.

Abbreviations: PK, pyruvate kinase; PTS, phosphotransferase system; LDH, lactate dehydrogenase; PEP, phosphoenolpyruvate; FBP, fructose 1,6-bisphosphate; G6P, glucose 6-phosphate; F6P, fructose 6-phosphate; CTAB, cetyltrimethylammonium bromide. 
Bacterial strains and culture media. Brevibacterium flavum No. 2247 (ATCC14067) (wild strain) and an aspartate-producing mutant lacking PK, No. 70, ${ }^{3)}$ were used. Medium 41, a modification of Medium 30, ${ }^{4)}$ was composed of $20 \mathrm{~g}$ of glucose, $10 \mathrm{~g}$ of ammonium sulfate, $3 \mathrm{~g}$ of urea, $1 \mathrm{~g}$ of $\mathrm{KH}_{2} \mathrm{PO}_{4}, 0.4 \mathrm{~g}$ of $\mathrm{MgSO}_{4} \cdot 7 \mathrm{H}_{2} \mathrm{O}, 0.5 \mathrm{~g}$ of $\mathrm{NaCl}, 10 \mathrm{mg}$ of $\mathrm{FeSO}_{4} \cdot 7 \mathrm{H}_{2} \mathrm{O}, 8 \mathrm{mg}$ of $\mathrm{MnSO}_{4} \cdot 4 \mathrm{H}_{2} \mathrm{O}$, $50 \mu \mathrm{g}$ of $d$-biotin, $200 \mu \mathrm{g}$ of thiamine $\cdot \mathrm{HCl}$ and $20 \mathrm{~g}$ of agar in a total volume of 1 liter, adjusted to $\mathrm{pH} 7.0$ with $\mathrm{KOH}$, and sterilized at $115^{\circ} \mathrm{C}$ for $10 \mathrm{~min}$. The composition of Medium $13^{5)}$ was the same as that of Medium 41 except that $\mathrm{NaCl}$ and agar were not added and that the concentrations of $d$-biotin and thiamine $\cdot \mathrm{HCl}$ were 30 and $100 \mu \mathrm{g}$ per liter, respectively. $\mathrm{NaOH}$ was used for $\mathrm{pH}$ adjustment. The complex media containing polypeptone, yeast extract and glucose, Medium $7^{5)}$ and Medium 27, ${ }^{6}$ and the synthetic media, Medium 296) and Medium 34, ${ }^{31}$ were reported in the previous papers.

\section{Enzyme preparation}

i) Sugar kinases and mannitol dehydrogenase. Crude enzyme extracts were prepared from cells cultured for $16 \mathrm{hr}$ in Medium 13 containing the indicated sugar instead of glucose, except that the culture times for the ribose and mannitol media were 24 and $40 \mathrm{hr}$, respectively. Cells were harvested by centrifugation, washed twice with $0.2 \% \mathrm{KCl}$,

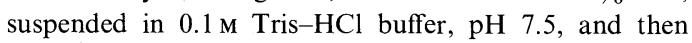
subjected to sonic disruption at $10 \mathrm{Kc}$ for $20 \mathrm{~min}$. After centrifugation of the sonicate at $170,000 \times g$ for $30 \mathrm{~min}$, the supernatant was gelfiltered through a Sephadex G-25 column with the same buffer.

ii) Sugar hydrolases and phosphorylases. Crude enzyme extracts were prepared as described above, except that $0.1 \mathrm{M}$ potassium phosphate buffer, $\mathrm{pH} 7.0$, was used instead of Tris- $\mathrm{HCl}$ buffer.

iii) PTS. Toluenized cells were used for the PTS assay. ${ }^{7)}$ Cells were cultured, harvested, washed as described above and then resuspended in a $0.1 \mathrm{M}$ Tris- $\mathrm{HCl}$ buffer, pH 7.5, supplemented with $10 \%$ polyethyleneglycol and $30 \mathrm{~mm}$ dithiothreitol. The cells were decryptified by adding $0.01 \mathrm{ml}$ of toluene to $1 \mathrm{ml}$ of the suspension, followed by vigorous agitation for $1 \mathrm{~min}$ with a mixer, Taiyo S-5F. The toluenized cell suspension was washed with and then resuspended in the same buffer.

iv) $P K$. Crude enzyme extracts for the $\mathrm{PK}$ assay were prepared by sonication as described previously ${ }^{3)}$ from cells cultured for $16 \mathrm{hr}$ in Medium 27. Cetyltrimethylammonium bromide (CTAB)-treated cells ${ }^{8)}$ were also used for the PK assay. Washed cells prepared by the above procedure and with an absorbancy at $562 \mathrm{~nm}$ of 0.7 after 26-fold dilution were treated with $0.6 \mathrm{~mm} \mathrm{CTAB}$ in $0.1 \mathrm{M}$ potassium phosphate buffer, $\mathrm{pH} 7.5$, at $37^{\circ} \mathrm{C}$ for $10 \mathrm{~min}$, and then resuspended in $0.1 \mathrm{M}$ Tris- $\mathrm{HCl}$ buffer, $\mathrm{pH}$ 7.5 , after centrifugation.

v) Oxaloacetate decarboxylase and malic enzyme. Crude enzyme extracts for the assay of these enzymes were prepared by the same procedure as for the sugar kinase assay, except that the cells for oxaloacetate decarboxylase and malic enzyme were cultured in a glucose medium, Medium 34, supplemented with $300 \mu \mathrm{g} /$ liter of biotin for $24 \mathrm{hr}$, and in Medium 29 containing $40 \mathrm{~g} /$ liter of glucose and $15 \mathrm{~g} /$ liter of ammonium sulfate instead of glutamate for $40 \mathrm{hr}$, respectively, and that the buffer for oxaloacetate decarboxylase was supplemented with $0.5 \mathrm{M}$ ammonium sulfate.

\section{Enzyme assay}

i) Sugar kinases. Glucokinase was assayed by measuring glucose 6-phosphate (G6P) formation according to the method of Anderson and Kamel, ${ }^{9)}$ while all other sugar kinases were assayed by measuring ADP formation as follows. The reaction mixture contained $50 \mathrm{mM}$ Tris $-\mathrm{HCl}$

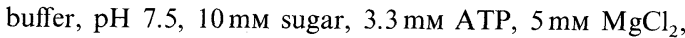
$2 \mathrm{~mm}$ PEP, $0.15 \mathrm{~mm}$ NADH, $10 \mu \mathrm{g}$ of PK, $10 \mu \mathrm{g}$ of lactate dehydrogenase (LDH) and enzyme in a total volume of $1.5 \mathrm{ml}$. The increase in absorbancy at $340 \mathrm{~nm}$ was measured. Control experiments were performed without sugar substrates. Gluconokinase was also assayed by measuring 6-phosphogluconate formation with the same reaction mixture as above, except that $0.4 \mathrm{~mm}$ NADP and $5 \mu \mathrm{g}$ of 6 phosphogluconate dehydrogenase were added instead of PEP, NADH, PK and LDH.

ii) Mannitol dehydrogenase. This enzyme was assayed by measuring the increase in absorbancy at $340 \mathrm{~nm}$ of the reaction mixture, which contained $50 \mathrm{~mm}$ sodium bicarbonate buffer, $\mathrm{pH}$ 10.0, $10 \mathrm{~mm}$ mannitol, $0.5 \mathrm{~mm}$ NAD and enzyme.

iii) Sugar phosphorylases. Sucrose phosphorylase and maltose phosphorylase were assayed by the method of Mieyal, ${ }^{10)}$ using sucrose and maltose, respectively, as substrates.

iv) Sugar hydrolases. Invertase and maltase were determined by measuring glucose formation according to the method of Goldstein and Lampen ${ }^{11)}$ for invertase.

v) PTS. This activity was assayed by measuring sugardependent pyruvate formation by the following procedure. The reaction mixture contained $100 \mathrm{~mm}$ Tris- $\mathrm{HCl}$ buffer, pH 7.5, $10 \mathrm{~mm}$ PEP, $5 \mathrm{~mm} \mathrm{MgCl}_{2}, 30 \mathrm{~mm}$ dithiothreitol, $10 \mathrm{~mm}$ sugar and $20 \mu \mathrm{l}$ of a toluenized cell suspension whose absorbancy at $562 \mathrm{~nm}$ was 0.5 after 250 -fold dilution. The mixture without sugar (total volume, $0.45 \mathrm{ml}$ ) was preincubated at $30^{\circ} \mathrm{C}$ for $10 \mathrm{~min}$. The reaction was started by the addition of $0.05 \mathrm{ml}$ of $100 \mathrm{~mm}$ sugar and stopped by adding $0.1 \mathrm{ml}$ of $30 \%$ metaphosphoric acid after $10 \mathrm{~min}$ incubation at $30^{\circ} \mathrm{C}$. After centrifugation, pyruvate produced in the supernatant was assayed. The composition of the assay mixture was $0.5 \mathrm{M}$ TES- $\mathrm{NaOH}$ buffer, $\mathrm{pH} 7.5,0.15 \mathrm{~mm} \mathrm{NADH}, 50 \mu \mathrm{g}$ of $\mathrm{LDH}$ and $0.1 \mathrm{ml}$ of the supernatant of the PTS reaction mixture in a final volume of $2.1 \mathrm{ml}$. Before and after addition of $\mathrm{LDH}$, the absorbancy at $340 \mathrm{~nm}$ was measured.

vi) $P K$. Two assay methods (A and $\mathrm{B}$ ) were used to assay PK. Method A involving crude enzyme extracts was described previously. ${ }^{3)}$ The composition of the reaction 
mixture for Method B with CTAB-treated cells was the same as that for Method A but without NADH and LDH. After the reaction had been carried out at $30^{\circ} \mathrm{C}$ for $10 \mathrm{~min}$, the mixture was placed in an ice bath and the cells were removed by centrifugation. Pyruvate formed was determined as described above.

vii) Oxaloacetate decarboxylase. The reaction mixture for the oxaloacetate decarboxylase assay contained $50 \mathrm{~mm}$ TES-NaOH buffer, $\mathrm{pH} 8.0,10 \mathrm{~mm} \mathrm{MnSO}_{4}, 10 \mathrm{~mm}$ oxaloacetate and enzyme in a final volume of $1.0 \mathrm{ml}$. The reaction was started by the addition of oxaloacetate after $5 \mathrm{~min}$ preincubation at $30^{\circ} \mathrm{C}$, allowed to proceed for $5 \mathrm{~min}$ at $30^{\circ} \mathrm{C}$, stopped by the addition of $0.2 \mathrm{ml}$ of $30 \%$ metaphosphoric acid, and then cooled in an ice bath. Pyruvate produced in the reaction mixture was measured as described above.

viii) Malic enzyme. This enzyme was assayed by measuring the absorbancy at $340 \mathrm{~nm}$ of the reaction mixture, which contained $33 \mathrm{~mm}$ Tris- $\mathrm{HCl}$ buffer, $\mathrm{pH} 7.5$, $33 \mathrm{~mm}$ malate, $0.27 \mathrm{~mm}$ NADP, $1 \mathrm{~mm} \mathrm{MnCl}_{2}, 200 \mathrm{~mm} \mathrm{KCl}$ and enzyme in a final volume of $1.5 \mathrm{ml}$.

Isolation of pyruvate kinase-deficient mutants. Mutants were derived from B. flavum No. 2247 cells grown in Medium 7 through treatment with $1 \mathrm{mg} / \mathrm{ml}$ of $N$-methyl$N^{\prime}$-nitro- $N$-nitrosoguanidine at $30^{\circ} \mathrm{C}$ for $15 \mathrm{~min}$, and selected from colonies grown on Medium 7-agar plates by the replica-plating melthod. After incubation for 24 or $48 \mathrm{hr}$ at $30^{\circ} \mathrm{C}$, colonies which grew on Medium 41 but not on Medium 41 containing ribose instead of glucose were picked up. From among them, mutants which required pyruvate for growth on the ribose medium were further selected. Their PK activities were assayed using CTABtreated cells and confirmed using cell-free extracts.

\section{RESULTS}

\section{Enzymes catalyzing the formation of pyruvate}

Strain No. $70^{3)}$ was isolated as a revertant with a normal level of homoserine dehydrogenase from strain 1-231 with a low level of the enzyme and lacking PK, which was derived from a $B$. flavum mutant, 15-8, and selected as to resistance to $S$-(2-aminoethyl)-L-cysteine and lysine-productivity. ${ }^{12,13)}$ The PK-lacking mutant, No. 70, was found to grow well on glucose (see Table III), suggesting that other reactions might also contribute to the pyruvate formation during growth on glucose. Possible enzymes catalyzing the reactions were examined; inducible fructose 1,6-bisphosphate (FBP)-dependent PK isozyme, oxaloacetate decarboxylase, malic enzyme, and PEP : sugar
PTS. Two distinct PKs, a constitutive AMPactivated enzyme and an inducible FBPdependent one, have been identified in Escherichia coli. ${ }^{14)}$ In a partially purified preparation of $B$. flavum, PK was found to be activated by AMP but not by FBP. ${ }^{2)}$ Furthermore, inducible FBP-dependent PK was undetectable in the crude enzyme extract of cells grown on glucose, as shown in Table I. On the other hand, oxaloacetate decarboxylase activity was considerably high in the wild-type strain. A PK mutant, No. 70, showed only $10 \%$ of the parental activity. Malic enzyme activated by $\mathrm{K}^{+}$was present at a high level in the wild strain grown on glutamate (the data will be presented in another report), but was essentially absent in the mutant. Since the enzyme activity after growth on glucose was very low in the wild strain and undetectable in the mutant, it was unlikely that the enzyme served to produce pyruvate during growth on glucose. PEP: glucose PTSs, catalyzing the formation of G6P and pyruvate from glucose and PEP, are widely distributed among bacteria which metabolize glucose through the Embden-Meyerhof-Parnas pathway. ${ }^{15}$ ) The PTS activity was assayed using toluenized cells by measuring the glucose-dependent pyruvate

\section{Table I. Specific Activities of Enzymes Catalyzing Pyruvate Formation in the B. flavum Wild Strain and Pyruvate KinASE-DEFICIENT MUTANT}

The experimental conditions were given under Materials AND Methods, except that the cells for the pyruvate kinase assay were cultured in Medium 34 supplemented with $300 \mu \mathrm{g} /$ liter of biotin, and that the reaction mixture for the FBP-dependent pyruvate kinase assay contained $1 \mathrm{~mm}$ FBP.

\begin{tabular}{lcc}
\hline $\begin{array}{c}\text { Specific activity } \\
\text { (nmol/min/mg protein) }\end{array}$ & $\begin{array}{c}2247 \\
\text { (Wild) }\end{array}$ & $\begin{array}{c}\text { No. 70 } \\
\left(\mathrm{PK}^{-}\right)\end{array}$ \\
\hline Pyruvate kinase & 809 & 2 \\
Oxaloacetate decarboxylase & 270 & 22 \\
Malic enzyme & 6.3 & 0.0 \\
Inducible FBP-dependent PK & 0 & 0 \\
PEP: glucose PTS* & 44 & 20
\end{tabular}

* $\mathrm{nmol} / \mathrm{min} /$ cells giving $1 \mathrm{mg}$ protein of cell free extract. 
Table II. Phosphoenolpyruvate: Glucose Phosphotransferase System in B. flavum No. 2247

The composition of the reaction mixture was given under Materials and Methods. G6P and F6P were determined by the method of Lang and Michal. ${ }^{19)}$

\begin{tabular}{llll}
\hline & \multicolumn{2}{c}{ Reaction time (min) } \\
\cline { 2 - 4 } & \multicolumn{2}{c}{5} & 30 \\
\hline \multicolumn{2}{c}{ Pyruvate formation $(\mu \mathrm{mol} / \mathrm{ml})$} & & \\
Complete $(1)$ & 0.38 & 2.10 \\
-Glucose & $(2)$ & 0.064 & 0.52 \\
- $\mathrm{Mg}^{2+}$ & $(3)$ & 0.028 & 0.24 \\
-Enzyme & $(4)$ & 0.00 & 0.00 \\
$(1)-(2)$ & 0.32 & 1.58
\end{tabular}

G6P formation $(\mu \mathrm{mol} / \mathrm{ml})$
$(1)-(2)$
0.22
0.62

G6P + F6P formation $(\mu \mathrm{mol} / \mathrm{ml})$

(1) $-(2)$

$0.28 \quad 0.76$

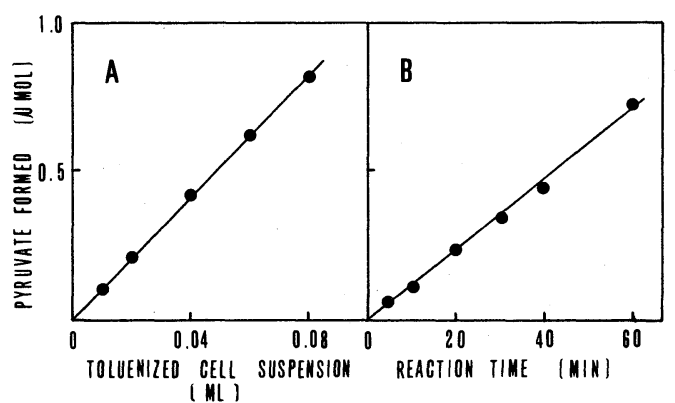

FIG. 1. Glucose-dependent Pyruvate Formation in $B$. flavum No. 2247.

Pyruvate formed was determined according to the PTS assay methods described under MATERIALS AND METHODS, except that the enzyme (toluenized cell suspension) volume used for the assay (A) and reaction time (B) were as indicated in the figures.

formation from PEP. Table II shows that pyruvate was produced from PEP in the presence of glucose and $\mathrm{Mg}^{2+}$, a reported essential cofactor. The formation of the other product, G6P, after $5 \mathrm{~min}$ reaction was only $60 \%$ of the pyruvate formation. The total formation of G6P and fructose 6-phosphate (F6P), to which it was converted via the isomerase reaction, corresponded to the pyruvate formation. This coincidence was not seen after
Table III. Growth on Various Sugars and the Effects of Pyruvate on the Growth of B. flavum No. 2247 AND A Pyruvate KinaseDEFiCient Mutant, No. 70

The growth response was observed after $48 \mathrm{hr}$ cultivation at $30^{\circ} \mathrm{C}$ on Medium 41 -agar plates containing the indicated sugars instead of glucose. The concentration of pyruvate added was $5 \mathrm{~g} /$ liter.

\begin{tabular}{|c|c|c|c|c|}
\hline \multirow{3}{*}{ Carbon source } & \multicolumn{4}{|c|}{ Growth } \\
\hline & \multicolumn{2}{|c|}{ No. 2247} & \multicolumn{2}{|c|}{ No. 70} \\
\hline & None & $\begin{array}{c}+ \\
\text { Pyruvate }\end{array}$ & None & $\begin{array}{c}+ \\
\text { Pyruvate }\end{array}$ \\
\hline Glucose & ++ & ++ & ++ & ++ \\
\hline Sucrose & ++ & & ++ & \\
\hline Fructose & ++ & & ++ & \\
\hline Maltose & ++ & & + & \\
\hline Gluconate & ++ & ++ & - \pm & ++ \\
\hline Ribose & ++ & ++ & - \pm & ++ \\
\hline Mannitol & ++ & & + & \\
\hline Mannose & - \pm & & - \pm & \\
\hline Galactose & - & & - & \\
\hline Lactose & - & & - & \\
\hline Sorbitol & - & & - & \\
\hline Glycerol & - & & - & \\
\hline $\begin{array}{l}\text { Glucose } \\
\text { 6-phosphate }\end{array}$ & - & & - & \\
\hline None & - & \pm & - & - \\
\hline
\end{tabular}

,- no growth; \pm , slight growth; ++ , normal growth.

30 min reaction, suggesting that the G6P formed was consumed to yield metabolites other than F6P. Washed toluenized cells were stabilized by polyethyleneglycol and dithiothreitol added to the cell suspension during their preparation. A time-lag arose at the initial step of the reaction on the omission of preincubation of the reaction mixture without glucose. Under the standard conditions, the plots of pyruvate formed against cell amount and those against reaction time (Fig. 1) were linear. Thus, the pyruvate formation represents PTS activity. The activity was found in both the wild and mutant strains, as shown in Table I.

\section{Growth response to various sugars of a pyruvate kinase-deficient mutant \\ If only the sugar-specific PTS substantially}


serves to produce pyruvate besides $\mathrm{PK}$, the PK-lacking mutant would not grow on sugars which were not catabolized by the PTS. Table III shows that whereas a PK-deficient mutant, No. 70, grew well on glucose or fructose as the wild strain did, it did not grow on gluconate or ribose, but did grow on them in the presence of pyruvate. These results suggest that only PK is responsible for the pyruvate formation during growth on gluconate or ribose, and that other reactions may also serve to produce pyruvate during growth on glucose or fructose. Only the PTS is known to cause such sugar-specific formation of pyruvate. ${ }^{15)}$

\section{Properties of the phosphoenolpyruvate: sugar phosphotransferase system}

PTS activities, with respect to various sugars, were examined in cells grown on the substrate sugars, because the system was often inducible. ${ }^{15}$ The activities for glucose, fructose, ribose, gluconate, mannitol, sucrose and maltose in cells grown on the respective substrate sugars were $31,58,7,1,3,5$ and $4 \mathrm{nmol} / \mathrm{min} / 20 \mu \mathrm{l}$ cell suspension, respectively. Thus, the enzyme was found to act on fructose, in addition to glucose. These activities were

Table IV. EFfects of Growth Carbon Sources on the Glucose- AND Fructose Phosphotransferase

SySTEM IN B. flavum No. 2247

The experimental conditions were given under in MATERIALS AND METHODS.

"Inducible fructose PTS" was calculated as described in the text. $\mathrm{Bg} / \mathrm{Ag}(=0.48)$ was obtained from an average of the data in this table and Table $\mathrm{V}$.

\begin{tabular}{lccc}
\hline \multicolumn{3}{c}{$\begin{array}{c}\text { PTS activity } \\
\text { Carbon source } \\
\text { for growth }\end{array}$} & (nmol/min/20 $\mu$ l of cell suspension) \\
\cline { 2 - 4 } & Glucose (A) & Fructose (B) & $\begin{array}{c}\text { "Inducible } \\
\text { fructose } \\
\text { PTS" }\end{array}$ \\
\hline Glucose & 38 & 22 & 4 \\
Fructose & 45 & 60 & 38 \\
Sucrose & 44 & 56 & 35 \\
Mannitol & 107 & 86 & 34 \\
Ribose & 95 & 49 & 3 \\
Gluconate & 34 & 29 & 13 \\
Maltose & 42 & 23 & 3 \\
\hline
\end{tabular}

also detected in cells grown on various sugars other than the substrate sugars, as shown in Table IV. The cells grown on ribose or mannitol had higher glucose PTS activities. This may be due to the difference in the growth phase at which the cells were harvested, since B. flavum grew slowly on ribose and very slowly on mannitol. The ratio of the activity on glucose to that on fructose varied among the cells grown on various carbon sources, suggesting that two or more PTSs might function. High fructose PTS activities were observed in cells grown on fructose, mannitol and sucrose. Thus, the operation of both an inducible fructose-specific PTS and a constitutive PTS with broad substrate specificities, acting on glucose and fructose, was assumed, the latter of which alone was thought to function in the glucose-grown cells. On the basis of this assumption, B/A (A, PTS activity for glucose; $\mathrm{B}$, that for fructose) in glucosegrown cells $(=\mathrm{Bg} / \mathrm{Ag})$ was thought to be the ratio of the constitutive PTS activities. In cells grown on other sugars, B should be the sum of the inducible fructose PTS activity and the constitutive PTS activity for fructose. The latter activity should be obtained as

Table V. Sugar Specificities of the Phosphotransferase System in B. flavum No. 2247 Cells Grown ON GLucose or Fructose

\begin{tabular}{lrr} 
& \multicolumn{2}{c}{ Relative activity* } \\
\multicolumn{1}{c}{$\begin{array}{c}\text { Substrate } \\
(10 \mathrm{~mm})\end{array}$} & Growth carbon source \\
\cline { 2 - 3 } & Glucose & Fructose \\
\cline { 2 - 3 } & & \\
\hline Glucose & 100 & 100 \\
Fructose & 39 & 127 \\
Mannose & 43 & 44 \\
Galactose & 1 & 1 \\
Lactose & 6 & 4 \\
Glycerol & 1 & 0 \\
Sorbitol & 3 & 1 \\
Xylose & 8 & 69 \\
2-Deoxyglucose & 80 & 117 \\
Glucosamine & 92 & 4 \\
N-Acetylglucosamine & 5 & 99 \\
\hline
\end{tabular}

* Relative activities for glucose as a substrate were taken as 100 . 
$\mathrm{A} \times \mathrm{Bg} / \mathrm{Ag}$. Thus, the inducible fructosespecific PTS activity was calculated according to the following equation, as shown in Table IV.

\section{Inducible fructose $\mathrm{PTS}=\mathrm{B}-\mathrm{A} \times \mathrm{Bg} / \mathrm{Ag}$}

A reasonable result was obtained that only cells grown on fructose, sucrose and mannitol, which gave fructose, a possible inducer, exhibited significant activities. An inducible fructose-specific PTS has been found to be widely distributed in bacteria such as E. coli. ${ }^{15)}$

The sugar specificities of the PTS were examined using glucose-grown cells. Table V shows that the PTS acted on mannose, 2deoxyglucose and glucosamine, in addition to glucose and fructose. It is interesting that the system operated in the phosphorylation of mannose which was hardly utilized by $B$. flavum as a carbon source for growth. On the other hand, the specificities of fructose-grown cells were similar to those of glucose-grown cells, except that the activity on fructose was specifically high. This also supports the presence of an inducible fructose-specific PTS in addition to the constitutive PTS.

\section{Enzymes for sugar metabolism}

Studies on the PTSs of B. flavum and on the growth response to various sugars of a PK- deficient mutant suggested the following relationship between sugar metabolism and pyruvate formation: (1) The PTSs indeed served to form pyruvate in addition to PK, when $B$. flavum grew on glucose or fructose, which seemed to be catabolized mainly via the PTS reaction. Thus, PK-lacking mutants grow on the sugars. (2) The PTS would also contribute to the formation of pyruvate during growth on sucrose, maltose or mannitol, since they seemed to be catabolized through the PTSs after conversion to glucose and/or fructose. PKdeficient mutants, therefore, grow on these sugars. (3) The PTS would not operate, when cells grew on ribose or gluconate, because they neither acted as substrates for the PTSs nor would yield glucose or fructose. Thus, PKdefective mutants are unable to grow on them. These suggestions were confirmed by the following determination of the possible enzyme activities for catabolism of the respective sugars.

The presence of glucokinase catalyzing ATP-dependent phosphorylation of glucose into G6P in B. flavum had been reported previously, ${ }^{16)}$ and this was confirmed, as shown in Table VI. Glucose-grown cells, however, exhibited much lower glucokinase activity than PTS activity, and the affinity of the former enzyme for glucose was relatively lower

Table VI. Enzyme Activities Related to Sugar Metabolism in B. flavum No. 2247

The experimental conditions were given under MAterials and Methods.

\begin{tabular}{|c|c|c|c|c|c|c|}
\hline \multicolumn{2}{|c|}{$\begin{array}{c}\text { Substrate }(\mathrm{mm}) \\
(=\text { Carbon source })\end{array}$} & \multirow{2}{*}{$\begin{array}{c}\text { PTS* } \\
44\end{array}$} & \multirow{2}{*}{$\begin{array}{c}\text { Kinase } \\
2.0\end{array}$} & \multirow{2}{*}{$\begin{array}{r}\begin{array}{r}\text { Dehydrogenase } \\
\text { (nmol/n }\end{array} \\
-\end{array}$} & \multirow{2}{*}{$\begin{array}{l}\text { Hydrolase } \\
\text { protein) }\end{array}$} & \multirow{2}{*}{$\begin{array}{c}\text { Phosphorylase } \\
-\end{array}$} \\
\hline Glucose & 10 & & & & & \\
\hline & 100 & & 2.7 & & & \\
\hline Fructose & 10 & 68 & 1.0 & - & - & - \\
\hline & 100 & & 1.7 & & & \\
\hline Ribose & 10 & 8 & 207 & - & - & - \\
\hline Gluconate & 10 & 1 & 251 & - & - & - \\
\hline Mannitol & 10 & 3 & 0 & 243 & - & - \\
\hline \multirow[t]{2}{*}{ Sucrose } & 10 & 6 & & - & & \\
\hline & 100 & & 0 & & 300 & 0 \\
\hline \multirow[t]{2}{*}{ Maltose } & 10 & 5 & & - & & \\
\hline & 100 & & 0 & & 163 & 0 \\
\hline
\end{tabular}

* $\mathrm{nmol} / \mathrm{min} /$ cells giving $1 \mathrm{mg}$ protein of cell free extract. -, not determined. 
than that of the latter, which was saturated by glucose at a concentration less than $10 \mathrm{~mm}$. Fructokinase activity was barely detected in cells grown on fructose. Ribose- and gluconate-grown cells had high ribokinase and gluconokinase activities, respectively. The latter activity was confirmed stoichiometrically by measuring both ADP and 6-phosphoglu- conate formation. Among possible mannitolcatabolic enzymes, mannitol kinase and mannitol dehydrogenase, only the latter enzyme was showed high activity in B. flavum. It was specific for NAD. The optimum $\mathrm{pH}$ for fructose formation was 10.0 and that for the reverse reaction, 7.0. Whereas kinase or phosphorylase activities for sucrose and maltose

Table VII. Effects of Growth Carbon Sources on Sugar-Metabolic Enzymes IN B. flavum No. 2247

Cells were cultured in Medium 13 containing $20 \mathrm{~g} /$ liter of a sugar or $10 \mathrm{~g} /$ liter each of two sugars as indicated instead of glucose.

\begin{tabular}{|c|c|c|c|c|c|}
\hline Carbon source & Ribokinase & $\begin{array}{l}\text { Gluconokinase } \\
\text { (nmol/m }\end{array}$ & $\begin{array}{l}\text { Mannitol } \\
\text { dehydrogenase } \\
\text { protein) }\end{array}$ & Maltase & Invertase \\
\hline Glucose & 16 & 34 & 3 & 54 & 278 \\
\hline Ribose & 207 & 32 & 12 & - & - \\
\hline Ribose + glucose & 141 & - & - & - & - \\
\hline Gluconate & 39 & 251 & - & - & - \\
\hline Gluconate + glucose & - & 201 & - & - & - \\
\hline Mannitol & - & - & 243 & - & - \\
\hline Mannitol+glucose & - & - & 15 & - & - \\
\hline Maltose & - & - & - & 163 & 368 \\
\hline Sucrose & - & - & - & 47 & 300 \\
\hline
\end{tabular}

- not determined.

Table ViII. Pyruvate Kinase Mutants Derived from B. flavum No. 2247

The bacterial strains were cultured at $30^{\circ} \mathrm{C}$ on agar plates of Medium 41 or the latter containing $20 \mathrm{~g}$ of ribose or $20 \mathrm{~g}$ of ribose and $5 \mathrm{~g}$ pyruvate per liter instead of glucose. Growth was observed after $48 \mathrm{hr}$.

\begin{tabular}{|c|c|c|c|c|c|}
\hline \multirow{2}{*}{ Strain } & \multicolumn{3}{|c|}{ Growth } & \multicolumn{2}{|c|}{ Pyruvate kinase } \\
\hline & Glucose & Ribose & Ribose + pyruvate & CTAB cell & Extracts* \\
\hline No. 2247 & ++ & ++ & ++ & $100 \%$ & 689 \\
\hline No. 70 & ++ & \pm & ++ & 0 & 0 \\
\hline P- 10 & ++ & - & + & 52 & \\
\hline 27 & ++ & - & ++ & 32 & \\
\hline 39 & ++ & - & ++ & 0 & 0 \\
\hline 47 & ++ & \pm & ++ & 2 & 0 \\
\hline 207 & ++ & - & ++ & 25 & \\
\hline 213 & ++ & - & + & - & \\
\hline 220 & ++ & \pm & + & 5 & 6 \\
\hline 226 & ++ & \pm & ++ & 101 & \\
\hline 233 & ++ & \pm & ++ & 100 & \\
\hline 234 & ++ & \pm & ++ & 14 & \\
\hline 236 & ++ & - & + & 40 & 97 \\
\hline 258 & ++ & \pm & ++ & 94 & \\
\hline
\end{tabular}

* $\mathrm{nmol} / \mathrm{min} / \mathrm{mg}$ protein.

- , not grown on the medium for enzyme preparation. 
were undetectable, the activities of hydrolases, i.e., invertase and maltase, were high.

Regulation of these enzymes by growth carbon sources was investigated. Table VII shows that ribokinase, gluconokinase and mannitol dehydrogenase were induced specifically by the respective substrate sugars, that mannitol dehydrogenase was also repressed by glucose, and that maltase was inducible whereas invertase was constitutive. Cells grown on maltose showed slightly higher invertase activity, suggesting the possibility that the induced maltase besides invertase served to form glucose from sucrose.

\section{Direct derivation of $P K$-deficient mutants from the wild strain}

We tried to derive PK-defective mutants by means of single mutation from the wild strain in order to confirm the essential role of PK in the growth on ribose, because the previous isolation of a PK-lacking mutant, No. 70, had been fairly complicated. As shown in Table VIII, twelve mutants unable to grow on ribose in the absence of pyruvate were isolated. Among them, three were defective in PK and five had low PK activity. All of the three PKlacking mutants, P-39, P-47 and P-220, were also unable to grow on gluconate. The oxaloacetate decarboxylase activities of strains P47 and P-220 were 365 and $28 \mathrm{nmol} / \mathrm{min} / \mathrm{mg}$ protein, whereas their malic enzyme activities were 25.5 and $4.6 \mathrm{nmol} / \mathrm{min} / \mathrm{mg}$ protein, respectively. Thus, it was found that even if oxaloacetate decarboxylase and malic enzyme were present at the normal levels, they could not serve to produce sufficient pyruvate for growth on ribose and gluconate.

\section{DISCUSSION}

The presence of the PTS was demonstrated in B. flavum. This is consistent with the general concept as to the distribution of the PTS in bacteria, ${ }^{15)}$ since $B$. flavum is a facultative anaerobe and catabolizes glucose mainly through the Embden-Meyerhof pathway. ${ }^{16,17)}$ The PTS catalyzes the sugar-dependent for- mation of pyruvate from PEP. Glucose and fructose were found to be PTS substrates among the sugars tested on which B. flavum grew. There would be two PTSs in B. flavum, the constitutive PTS which exhibited broad substrate specificity, acting upon glucose, fructose, mannose, 2-deoxyglucose and glucosamine, and the inducible fructose-specific PTS. They are similar to the mannose PTS and fructose PTS in E. coli, respectively.

PK-defective mutants grew on sugars which were thought to be phosphorylated by or catabolized through the PTS but did not grow specifically on ribose or gluconate, on which the PTS did not operate directly or indirectly, suggesting that only PK and PTS contributed to the pyruvate formation during the growth on sugars. In addition, oxaloacetate decarboxylase and malic enzyme were found not to serve to supply pyruvate under such conditions. An outline of the relationship between pyruvate formation and sugar metabolism in B. flavum is given in Fig. 2.

The presence of glucokinase catalyzing the ATP-dependent phosphorylation of glucose



FIG. 2. Sugar Metabolism and Pyruvate Formation in B. flavum.

1, PEP:sugar PTS; 2, ribokinase; 3, gluconokinase; 4, maltase; 5, invertase; 6, mannitol dehydrogenase; 7, pyruvate kinase.

Abbreviations: P, phosphate; DHAP, dihydroxyacetone phosphate; GAP, glyceraldehyde 3-phosphate; PEP, phosphoenolpyruvate. 
had been reported previously. ${ }^{16)}$ In the present study, the PTS was found to exhibit approximately 20-times higher activity than glucokinase, suggesting that glucose was phosphorylated by the PTS at the expense of PEP rather than by ATP-dependent kinase. Thus, one of the two molecules of PEP yielded from one molecule of glucose would be consumed for the phosphorylation of glucose to yield pyruvate. Moreover, a part of the other one would also yield pyruvate via the PK reaction. This explains the increases in the productivity of aspartate $^{3)}$ and lysine ${ }^{13)}$ caused by a PK deficiency, which saves PEP, because they are produced from PEP, and from equal amounts of PEP and pyruvate, respectively. Only one fortuitously isolated PK-lacking mutant had previously been available to improve these amino acid productivities by means of a PK deficiency. Therefore, it is industrially significant that the easy selection of PK-deficient mutants from any parent strains has become possible. We have already obtained improved lysine-producing mutants with a PK deficiency by means of the present method. The details will be given in a separate paper.

Pyruvate formation in E. coli is thought to be catalyzed by constitutive AMP-activated PK, an inducible FBP-dependent one, the PTS, and the methylglyoxal by-pass under glycolytic conditions. Since the methylglyoxal by-pass can only function to a very slight extent for pyruvate formation, PK and the PTS contribute to most of the formation, ${ }^{18)}$ as in B. flavum. Because of the presence of PK isozymes, however, it would be hard to isolate PK-lacking mutants as mutants unable to grow on non-PTS sugars which did not yield PTS sugars.

As to the metabolism of sugars other than glucose, gluconokinase was specifically induced when $B$. flavum grew on gluconate. Thus, gluconate seems to be catabolized through 6-phosphogluconate. Since PK was essential for the growth on gluconate, no significant operation of the Entner-Doudoroff pathway, where one molecule of pyruvate is formed from one molecule of gluconate, would occur. Gluconate is thought to be catabolized through the pentose phosphate pathway, whose presence in this organism has been proved by tracer-experiments ${ }^{17)}$ on $\mathrm{CO}_{2}$ and pyruvate formation from ${ }^{14} \mathrm{C}$-glucose. The PTS in B. flavum was unable to act on ribose. Therefore, PK was essential for growth on it. On the other hand, inducible ribokinase was present that catalyzed the phosphorylation of ribose. Thus, it appears to be catabolized via the kinase reaction and the pentose phosphate pathway. Since mannitol can yield fructose through the mannitol dehydrogenase reaction, which seems to be catabolized through the PTS reaction, PK is not necessary for growth on it. Sucrose and maltose appear to be hydrolysed by constitutive invertase and inducible maltase into glucose and/or fructose, respectively, which are thought to be phosphorylated through the PTS. Thus, PK is not indispensable for growth on these sugars.

Acknowledgments. The authors are indebted to Dr. Y. Komachiya and Dr. R. Tsugawa of their laboratories for the encouragement during this study.

\section{REFERENCES}

1) M. Mori and I. Shiio, J. Biochem., 98, 1621 (1985).

2) H. Ozaki and I. Shiio, J. Biochem., 66, 297 (1969).

3) M. Mori and I. Shiio, Agric. Biol. Chem., 48, 1189 (1984).

4) S. Sugimoto and I. Shiio, Agric. Biol. Chem., 46, 2711 (1982).

5) I. Shiio and K. Ujigawa, J. Biochem., 84, 647 (1978).

6) I. Shiio, H. Ozaki and M. Mori, Agric. Biol. Chem., 46, 493 (1982).

7) A. H. Romano, J. D. Trifone and M. Brustolon, J. Bacteriol., 139, 93 (1979).

8) I. Shiio, S. Otsuka and M. Takahashi, J. Biochem., 51, 56 (1962).

9) R. L. Anderson and M. Y. Kamel, "Methods in Enzymology," Vol. IX, ed. by W. A. Wood, Academic Press Inc., New York, 1966, p. 388.

10) J. J. Mieyal, "Methods in Enzymology," Vol. XXVIII, ed. by V. Ginsburg, Academic Press Inc., New York, 1972, p. 935.

11) A. Goldstein and J. O. Lampen, "Methods in Enzymology," Vol. XLII, ed. by W. A. Wood, Academic Press Inc., New York, 1975, p. 504.

12) I. Shiio, H. Ozaki and K. Ujigawa-Takeda, Agric. Biol. Chem., 46, 101 (1982).

13) H. Ozaki and I. Shiio, Agric. Biol. Chem., 47, 1569 
(1983).

14) M. Malcovati and H. L. Kornberg, Biochim. Biophys. Acta, 178, 420 (1969).

15) H. M. Saier, Jr., Bacteriological Reviews, 41, 856 (1977).

16) I. Shiio, S. Otsuka and T. Tsunoda, J. Biochem., 46, 1303 (1959).
17) I. Shiio, S. Otsuka and T. Tsunoda, J. Biochem., 47, 414 (1960).

18) A. G. Pertierra and R. A. Cooper, J. Bacteriol., 129, 1208 (1977).

19) G. Lang and G. Michal, "Methods of Enzymatic Analysis," Vol. 3, ed. by H. U. Bergmeyer, Academic Press Inc., New York, 1974, p. 1238. 